\title{
A solitary verrucose pruritic plaque on the penile shaft
}

\author{
Shahin Hamzelou, ${ }^{1}$ Ali Sadeghinia, ${ }^{1}$ Seyyed Farshad Allameh, ${ }^{2}$ Masood Jafari ${ }^{1}$
}

${ }^{1}$ Department of Dermatology, Tehran University of Medical Sciences, Razi Hospital, Tehran, Islamic Republic of Iran ${ }^{2}$ Department of Internal Medicine, Tehran University of Medical Sciences, Imam Khomeini Hospital, Tehran, Islamic Republic of Iran

\section{Correspondence to}

Dr Seyyed Farshad Allameh, farshad125@yahoo.com

Accepted 3 October 2014
CrossMark

To cite: Hamzelou $S$, Sadeghinia A, Allameh SF, et al. BMJ Case Rep Published online: [please include Day Month Year] doi:10.1136/bcr-2014204827

\section{DESCRIPTION}

A 50-year-old man presented with a small solitary pink-to-skin coloured plaque of 1 year duration on his penile shaft. The surface of the plaque was verrucose and not inflamed (figure 1). The patient mentioned severe pruritus. He had recent sexual exposure and did not have any other lesions.

Penile dermatoses are of great concern to patients and inflect psychological trauma. ${ }^{1}$ A patient who presents for an evaluation of a penile lesion is probably anxious, embarrassed and afraid. One of his biggest worries is, no doubt, whether he has contracted a sexually transmitted infection and, if so, whether he has infected his partner. ${ }^{2}$ A general belief among patients and many physicians is that most penile dermatoses result from infections. Prompt recognition of these lesions helps to avoid damage to feelings and sexual relationships of patients. ${ }^{1}$

In this case the following differential diagnoses were proposed: Lichen simplex chronicus (LSC), because of its severe pruritus; Wart, because of its verrucose appearance; and Bowen's disease, because of its scales.

Anogenital LSC (AGLSC) is a common condition seen by dermatologists. In a study in India, the frequency of AGLSC as a cause of anogenital pruritus was $2.54 \%$. As that study showed, the most common site of involvement of LSC in male genitalia is the scrotum. As we see in practice, the Indian study also demonstrated that the penile shaft involvement of LSC is very rare $(8.4 \%)$. So we could not be sure that the lesion was LSC, although it had severe pruritus.

Penile condylomas appear as papules or plaques and have a pebbled surface and are often the same colour as the surrounding skin. Large lesions may become pedunculated and cauliflower-like. Penile condyloma is the most common sexually transmitted disease. ${ }^{2}$ As our patient had recently had sexual contact and as, in the clinical examination, the lesion was verrucose we considered warts as the second differential diagnosis.

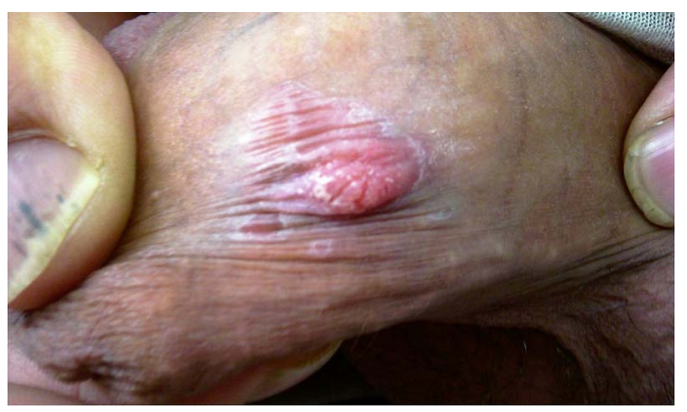

Figure 1 A pink solitary verrucose plaque on the penile shaft.
Bowen's disease is the most common type of carcinoma of the penis. Usually located on the penile shaft, it presents as a pink, well-demarcated dry patch or plaque that can be scaly. ${ }^{2}$

A biopsy was performed and the pathology examination revealed compact hyperkeratosis and psoriasiform acanthosis, which was characteristic for LSC (figure 2).

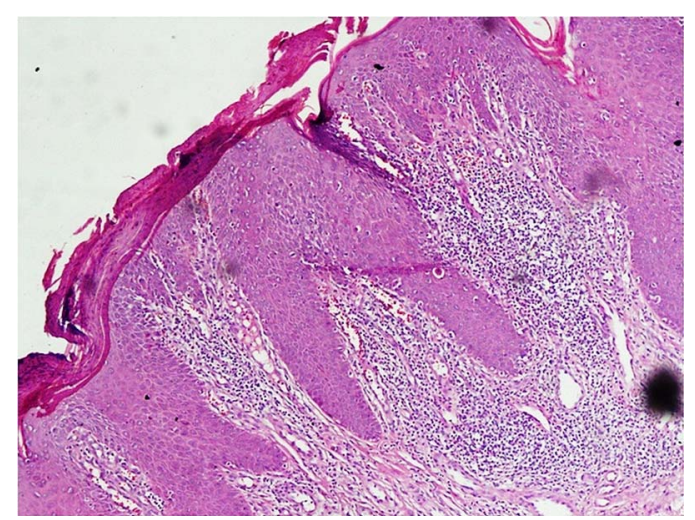

Figure 2 Compact hyperkeratosis plus acanthosis.

\section{Learning points}

It is important to consider Lichen simplex chronicus (LSC) as a differential diagnosis for penile lesions and to not assume every penile lesion is a sexually transmitted disease.

- In cases of severe pruritus, if the penile lesion has a verrucose appearance, which could be misdiagnosed as warts, we should also consider LSC, because severe intractable pruritus is the hallmark of LSC and is present in almost all cases. ${ }^{3}$

Contributors AS was involved in patient care. SH and SFA wrote the main draft of the manuscript and MJ provided the pictures.

Competing interests None.

Patient consent Obtained.

Provenance and peer review Not commissioned; externally peer reviewed.

\section{REFERENCES}

1 Al-Mashhadani SA. Penile dermatoses in out-patient dermatological clinic. Iraqi J Comm Med 2006:268-71.

2 Gogstetter DS, Mercurio MG. Common penile lesions: tips to the differential. 2001.

3 Rajalakshmi R, Thappa DM, Jaisankar TJ, et al. Lichen simplex chronicus of anogenital region: a clinico-etiological study. Indian J Dermatol Venereol Leprol 2011;77:28-36. 
Copyright 2014 BMJ Publishing Group. All rights reserved. For permission to reuse any of this content visit http://group.bmj.com/group/rights-licensing/permissions.

BMJ Case Report Fellows may re-use this article for personal use and teaching without any further permission.

Become a Fellow of BMJ Case Reports today and you can:

- Submit as many cases as you like

- Enjoy fast sympathetic peer review and rapid publication of accepted articles

- Access all the published articles

- Re-use any of the published material for personal use and teaching without further permission

For information on Institutional Fellowships contact consortiasales@bmjgroup.com

Visit casereports.bmj.com for more articles like this and to become a Fellow 